\title{
Syntheses, X-Ray Single Crystal Structures and Biological Activities of Cobalt(III) Complexes with Reduced Schiff Base Ligands
}

\author{
Xiao-Qiang Luo, ${ }^{1,2}$ Qiao-Ru Liu, ${ }^{1}$ Yong-Jun $\operatorname{Han}^{1}$ and Ling-Wei Xue ${ }^{1,2, *}$ \\ ${ }^{1}$ School of Chemical and Environmental Engineering, Pingdingshan University, Pingdingshan Henan 467000, P.R. China \\ ${ }^{2}$ Henan Key Laboratory of Research for Central Plains Ancient Ceramics, Pingdingshan University, \\ Pingdingshan Henan 467000, P.R. China \\ *Corresponding author: E-mail: pdsuchemistry@163.com
}

Received: 06-08-2019

\begin{abstract}
A new mononuclear cobalt(III) complex, [ $\left.\mathrm{Co}\left(\mathrm{HL}^{1}\right)_{2}\right] \mathrm{Cl}(\mathbf{1})$, derived from the reduced Schiff base 2,2'-((ethane-1,2-diylbis(azanediyl))bis(methylene)) diphenol $\left(\mathrm{H}_{2} \mathrm{~L}^{1}\right)$, and a new dinuclear cobalt(III) complex, $\left[\mathrm{Co}_{2}\left(\mathrm{~L}^{2}\right)_{2}\right] \cdot 2 \mathrm{H}_{2} \mathrm{O}(2)$, derived from the reduced Schiff base 6,6'-(2-hydroxypropane-1,3-diyl)bis(azanediyl)bis(methylene)bis(2-bromo-4-chlorophenol) $\left(\mathrm{H}_{2} \mathrm{~L}^{2}\right)$, were synthesized and characterized by infrared and electronic spectroscopy, and single crystal X-ray diffraction techniques. The ligands were synthesized first, and then bound to the Co(III) centre. Compound $\mathbf{1}$ contains a mononuclear $\left[\mathrm{Co}\left(\mathrm{HL}^{1}\right)_{2}\right]^{+}$cation and a chloride anion. The cationic moiety possesses crystallographic inversion center symmetry. Compound 2 contains a dinuclear $\left[\mathrm{Co}_{2}\left(\mathrm{~L}^{2}\right)_{2}\right]$ molecule and two water hydrate molecules. The Co atoms in the complexes are in octahedral coordination. Both complexes showed potential antimicrobial activity.
\end{abstract}

Keywords: Cobalt complex; reduced Schiff base ligand; crystal structure; antimicrobial activity

\section{Introduction}

Schiff bases derived from the condensation reactions of carbonyl containing compounds with primary amines have received tremendous attention in coordination chemistry because of their facile coordination ability to a large number of metals. ${ }^{1}$ Schiff bases have various biological applications. ${ }^{2}$ A number of complexes with Schiff base ligands have presented interesting biological properties, such as antibacterial, antifungal, antitumor, and enzymatic catalytic property. ${ }^{3}$ The Schiff bases have good complexing ability and their biological activity increases on complex with metal ions. ${ }^{4}$ Multi-dentate Schiff base ligands containing both nitrogen and oxygen donor atoms, derived from the condensation of salicylaldehyde and various diamines have intensely been studied, due to their ability to stabilize a great variety of coordination numbers and coordination geometries. ${ }^{5}$ Cobalt(III) Schiff base complexes are also important in bioinorganic chemistry for important biological processes like antibacterial, antitumor, and antifungal activities. ${ }^{6}$ However, Schiff bases are not very stable in acid condition due to the azomethine groups. Reduced Schiff bases are in general more stable than Schiff bases. In this paper, two new cobalt(III) complexes, $\left[\mathrm{Co}\left(\mathrm{HL}^{1}\right)_{2}\right] \mathrm{Cl}(\mathbf{1})$ and $\left[\mathrm{Co}_{2}\left(\mathrm{~L}^{2}\right)_{2}\right] \cdot 2 \mathrm{H}_{2} \mathrm{O}(2)$, where $\mathrm{HL}^{1}$ and $\mathrm{L}^{2}$ are the monoanionic form of the reduced Schiff base 2,2'-((ethane-1,2-diylbis(azanediyl))bis(methylene) diphenol $\left(\mathrm{H}_{2} \mathrm{~L}^{1}\right)$ and the trianionic form of the re-<smiles>Oc1ccccc1CNCCNCc1ccccc1O</smiles><smiles>Oc1c(Br)cc(Cl)cc1CNCC(O)CNCc1cc(Cl)cc(Br)c1O</smiles>

Scheme 1. $\mathrm{H}_{2} \mathrm{~L}^{1}$ and $\mathrm{H}_{3} \mathrm{~L}^{2}$. 
duced Schiff base 6,6'-(2-hydroxypropane-1,3-diyl)bis (azanediyl)bis(methylene)bis(2-bromo-4-chlorophenol) $\left(\mathrm{H}_{3} \mathrm{~L}^{2}\right.$; Scheme 1$)$, were synthesized and studied on their antibacterial potential.

\section{Experimental}

\section{1. General Methods and Materials}

All reagents and solvents were purchased from the commercial sources and used as received. Elemental (C, H and N) analyses were performed on a Perkin-Elmer 2400 II analyzer. IR spectra were recorded in the region 4000$400 \mathrm{~cm}^{-1}$ on a Perkin Elmer IR RXI spectrometer with samples as $\mathrm{KBr}$ disks. UV-Vis spectra were recorded on a Shimadzu UV-3600 spectrophotometer. Molar conductivity was measured at $25{ }^{\circ} \mathrm{C}$ with a DDS-11A conductivity meter. The NMR spectra were recorded on a Bruker spectrometer at $300 \mathrm{MHz}$. X-ray diffraction was carried out on a Bruker Apex II CCD diffractometer.

\section{2. Synthesis of $\mathrm{H}_{2} \mathrm{~L}^{1}$}

To salicylaldehyde (1.22 g, $10 \mathrm{mmol})$ diluted by $\mathrm{MeOH}(50 \mathrm{~mL}), 1,2$-diaminoethane $(0.30 \mathrm{~g}, 5 \mathrm{mmol})$ diluted by $\mathrm{MeOH}(50 \mathrm{~mL})$ was added with stirring. The reaction mixture was refluxed for $1 \mathrm{~h}$ and cooled by ice-water bath. Then, $\mathrm{NaBH}_{4}(1.0 \mathrm{~g}, 25 \mathrm{mmol})$ was added. The mixture was stirred for another $1 \mathrm{~h}$ and filtered. The solvent was removed by distillation. The residue was treated with the aqueous solution of $1 \mathrm{M} \mathrm{NaOH}(50 \mathrm{~mL})$ and extracted by chloroform. The solution was treated with $3 \mathrm{M} \mathrm{HCl}$ and the acid phase was made basic by $1 \mathrm{M} \mathrm{NaOH}$. The crude product was then extracted into chloroform. The chloroform extracts were combined and dried over anhydrous $\mathrm{Na}_{2} \mathrm{SO}_{4}$. The solvent was removed to give the colorless product. Yield $0.9 \mathrm{~g}(66 \%)$. IR data $\left(v, \mathrm{~cm}^{-1}\right): 3337,3212$, $3061,2983,2930,2855,1600,1481,1075$. UV-Vis data $\left(\mathrm{MeOH} ; \lambda_{\max }, \mathrm{nm}\right): 260,285 .{ }^{1} \mathrm{H}$ NMR $\left(300 \mathrm{MHz}, \mathrm{CDCl}_{3}\right.$, ppm) $\delta 7.06$ (q, 2H, ArH), 7.03 (d, 2H, ArH), 6.91 (q, 2H, ArH), 6.77 (d, $2 \mathrm{H}, \mathrm{ArH}), 3.85\left(\mathrm{~s}, 4 \mathrm{H}, \mathrm{CH}_{2}\right), 2.61(\mathrm{t}, 4 \mathrm{H}$, $\mathrm{CH}_{2}$ ). Anal. Calcd. (\%) for $\mathrm{C}_{16} \mathrm{H}_{20} \mathrm{~N}_{2} \mathrm{O}_{2}$ : C, 70.56; H, 7.40; N, 10.29. Found (\%): C, 70.45; H, 7.47; N, 10.23.

\section{3. Synthesis of $\mathrm{H}_{3} \mathrm{~L}^{2}$}

$\mathrm{H}_{3} \mathrm{~L}^{2}$ was prepared by the same method as described for $\mathrm{H}_{2} \mathrm{~L}^{1}$, with salicylaldehyde replaced by 3-bromo-5-chlorosalicylaldehyde $(2.34 \mathrm{~g}, 10 \mathrm{mmol})$, and with 1,2-diaminoethane replaced by 1,3-diaminopropan-2-ol $(0.45 \mathrm{~g}, 5 \mathrm{mmol})$. Yield $1.6 \mathrm{~g}(61 \%)$. IR data $\left(v, \mathrm{~cm}^{-1}\right)$ : $3382,3235,3053,2977,2941,2872,1597,1478,1081$. UVVis data $\left(\mathrm{MeOH} ; \lambda_{\max }, \mathrm{nm}\right): 255,273 .{ }^{1} \mathrm{H}$ NMR $(300 \mathrm{MHz}$, $\left.\mathrm{CDCl}_{3}, \mathrm{ppm}\right) \delta 11.83(\mathrm{~s}, 1 \mathrm{H}, \mathrm{OH}), 7.41(\mathrm{~s}, 2 \mathrm{H}, \mathrm{ArH}), 7.23$ (s, $2 \mathrm{H}, \mathrm{ArH}), 3.71\left(\mathrm{~d}, 4 \mathrm{H}, \mathrm{CH}_{2}\right), 3.67(\mathrm{~m}, 1 \mathrm{H}, \mathrm{CH}), 2.68$ (t, $4 \mathrm{H}, \mathrm{CH}_{2}$ ). Anal. Calcd. (\%) for $\mathrm{C}_{17} \mathrm{H}_{18} \mathrm{Br}_{2} \mathrm{ClN}_{2} \mathrm{O}_{3}$ :
C, 38.59; H, 3.43; N, 5.30. Found (\%): C, 38.44; H, 3.52; N, 5.27 .

\section{4. Synthesis of Complex 1}

A solution of $\mathrm{H}_{2} \mathrm{~L}^{1}$ (54.4 mg, $0.20 \mathrm{mmol}$ ) in $\mathrm{MeOH}$ $(10 \mathrm{~mL})$ was added dropwise with stirring at room temperature to a solution of $\mathrm{CoCl}_{2} \cdot 6 \mathrm{H}_{2} \mathrm{O}(23.8 \mathrm{mg}, 0.10 \mathrm{mmol})$ in $\mathrm{MeOH}(10 \mathrm{~mL})$. The solution immediately became deep brown and was stirred for $1 \mathrm{~h}$. Single crystals suitable for $\mathrm{X}$-ray diffraction were obtained after 11 days by slow evaporation of the reaction solution. Yield: $23 \mathrm{mg}(36 \%)$. IR data $\left(v, \mathrm{~cm}^{-1}\right): 3245,1218,1073$. UV-Vis data $\left(\mathrm{MeOH} ; \lambda_{\max }, \mathrm{nm}\right)$ : 280, 372. $\Lambda_{\mathrm{M}}\left(10^{-3} \mathrm{~mol} \mathrm{~L}^{-1}\right.$ in $\left.\mathrm{MeOH}\right): 151 \Omega^{-1} \mathrm{~cm}^{2} \mathrm{~mol}^{-1}$. Anal. Calcd. (\%) for $\mathrm{C}_{32} \mathrm{H}_{38} \mathrm{ClCoN}_{4} \mathrm{O}_{4}: \mathrm{C}, 60.33 ; \mathrm{H}, 6.01 ; \mathrm{N}$, 8.79. Found (\%): C, $60.46 ; \mathrm{H}, 6.12 ; \mathrm{N}, 8.76$.

\section{5. Synthesis of Complex 2}

Complex 2 was prepared by the same method as described for complex 1, with $\mathrm{H}_{2} \mathrm{~L}^{1}$ replaced by $\mathrm{H}_{3} \mathrm{~L}^{2}(52.9 \mathrm{mg}$, $0.10 \mathrm{mmol})$, and with $\mathrm{CoCl}_{2} \cdot 6 \mathrm{H}_{2} \mathrm{O}$ replaced by $\mathrm{Co}\left(\mathrm{CH}_{3}\right.$ $\mathrm{COO})_{2} \cdot 4 \mathrm{H}_{2} \mathrm{O}(24.9 \mathrm{mg}, 0.10 \mathrm{mmol})$. Single crystals suitable for X-ray diffraction were obtained after 3 days by slow evaporation of the reaction solution. Yield: $23 \mathrm{mg}(38 \%)$. IR data $\left(v, \mathrm{~cm}^{-1}\right): 3419,3246,1587,1443,1303,1274,1213$, $1169,1085,861,730,605$. UV-Vis data $\left(\mathrm{MeOH} ; \lambda_{\max }, \mathrm{nm}\right)$ : 210, 263, 317, 372. $\Lambda_{\mathrm{M}}\left(10^{-3} \mathrm{~mol} \mathrm{~L}^{-1}\right.$ in $\left.\mathrm{MeOH}\right): 21 \Omega^{-1} \mathrm{~cm}^{2}$ mol ${ }^{-1}$. Anal. Calcd. (\%) for $\mathrm{C}_{34} \mathrm{H}_{34} \mathrm{Br}_{4} \mathrm{Cl}_{4} \mathrm{Co}_{2} \mathrm{~N}_{4} \mathrm{O}_{9}$ : C, 33.42; $\mathrm{H}, 2.80 ; \mathrm{N}, 4.59$. Found (\%): C, 33.56; H, 2.87; N, 4.47.

\section{6. X-ray Crystallography}

The crystallographic data for the complexes are summarized in Table 1. Diffraction data of the complexes were collected on a Bruker APEX II CCD diffractometer at 298(2) K using graphite-monochromated Mo Ka radiation $(\lambda=0.71073 \AA)$. For data processing and absorption correction the packages SAINT and SADABS were used. ${ }^{7}$ The structures were solved by direct and Fourier methods and refined by full-matrix least-squares based on $F^{2}$ using SHELXTL and SHELXL-97 packages. $^{8}$ The non-hydrogen atoms were refined anisotropically. The hydrogen atoms on water molecules and the amino groups of complex 2 were located from a Fourier difference map and refined isotropically, with $\mathrm{O}-\mathrm{H}, \mathrm{N}-\mathrm{H}$ and $\mathrm{H} \cdots \mathrm{H}$ distances restrained to $0.85(1), 0.90(1)$ and $1.37(2) \AA$, respectively. The structure of complex 2 containing solvent accessible voids of $236 \AA^{3}$ may accommodate disordered solvent molecules. The remaining hydrogen atoms were inserted on geometrical calculated positions with fixed thermal parameters and were refined isotropically.

CCDC 1906730 and 1946056 contain the supplementary crystallographic data for the complexes $\mathbf{1}$ and $\mathbf{2}$, respectively. The data can be obtained free of charge via http://www.ccdc.cam.ac.uk/conts/retrieving.html, or from 
Table 1. Crystallographic and refinement data for the complexes

\begin{tabular}{|c|c|c|}
\hline & 1 & 2 \\
\hline Formula & $\mathrm{C}_{32} \mathrm{H}_{38} \mathrm{ClCoN}_{4} \mathrm{O}_{4}$ & $\mathrm{C}_{34} \mathrm{H}_{34} \mathrm{Br}_{4} \mathrm{Cl}_{4} \mathrm{Co}_{2} \mathrm{~N}_{4} \mathrm{O}_{9}$ \\
\hline FW & 637.04 & 1221.95 \\
\hline Crystal system & Monoclinic & Monoclinic \\
\hline Space group & $C 2 / c$ & $P 2_{1} / c$ \\
\hline$a(\AA)$ & $23.905(1)$ & $15.732(2)$ \\
\hline$b(\AA)$ & $7.376(1)$ & $12.478(2)$ \\
\hline$c(\AA)$ & $17.745(1)$ & $23.992(3)$ \\
\hline$\beta\left(^{\circ}\right)$ & $95.753(1)$ & $103.727(2)$ \\
\hline$V\left(\AA^{3}\right)$ & $3113.2(6)$ & $4575.2(9)$ \\
\hline$Z$ & 4 & 4 \\
\hline$\mu(\mathrm{MoK \alpha})\left(\mathrm{cm}^{-1}\right)$ & 0.679 & 4.504 \\
\hline Collected reflections & 8606 & 26672 \\
\hline Unique reflections & 2861 & 8507 \\
\hline Observed reflections $[I \geq 2 \sigma(I)]$ & 1591 & 4823 \\
\hline Parameters & 192 & 514 \\
\hline Restraints & 0 & 6 \\
\hline Goodness of fit on $F^{2}$ & 0.947 & 1.039 \\
\hline$R_{1}, w R_{2}[I \geq 2 \sigma(I)]$ & $0.0532,0.1031$ & $0.0718,0.2049$ \\
\hline$R_{1}, w R_{2}$ (all data) & $0.1275,0.1307$ & $0.1345,0.2399$ \\
\hline
\end{tabular}

the Cambridge Crystallographic Data Centre, 12 Union Road, Cambridge CB2 1EZ, UK; fax: (+44) 1223-336-033; or e-mail: deposit@ccdc.cam.ac.uk.

\section{7. Antibacterial Activity}

The antibacterial activities were tested against B. subtilis, E. coli, P. fluorescence and S. aureus using MH medium
(Mueller-Hinton medium). The MICs (minimum inhibitory concentrations) of the test compounds were determined by a colorimetric method using the dye MTT [3-(4,5-dimethylthiazol-2-yl)-2,5-diphenyltetrazolium bromide]. A stock solution of the synthesized compound $\left(50 \mu \mathrm{g} \mathrm{mL}^{-1}\right)$ in DMSO was prepared and quantities of the test compounds were incorporated in specified quantity of sterilized liquid MH medium. A specified quantity of the

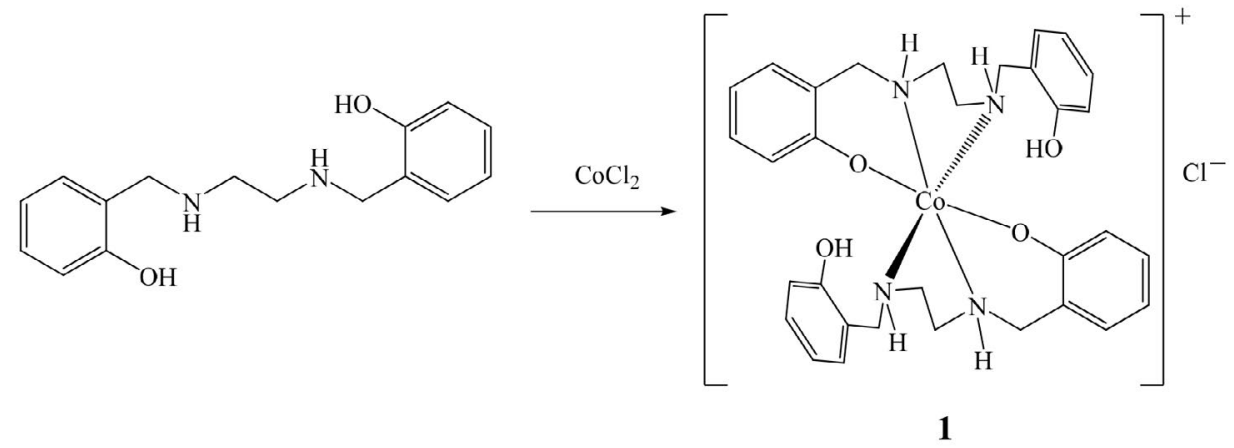<smiles>Oc1c(Br)cc(Cl)cc1CNCC(O)CNCc1cc(Cl)cc(Br)c1O</smiles>

Scheme 2. The synthetic procedure of the complexes. 
medium containing the compound was poured into micro-titration plates. A suspension of the microorganism was prepared to contain approximately $10^{5} \mathrm{cfu} \mathrm{mL}^{-1}$ and applied to micro-titration plates with serially diluted compounds in DMSO to be tested and incubated at $37^{\circ} \mathrm{C}$ for 24 h. After the MICs were visually determined on each of the micro-titration plates, $50 \mu \mathrm{L}$ of PBS containing $2 \mathrm{mg}$ of MTT per millilitre was added to each well. Incubation was continued at room temperature for $4-5 \mathrm{~h}$. The content of each well was removed and $100 \mu \mathrm{L}$ of isopropanol containing hydrochloric acid was added to extract the dye. After 12 $\mathrm{h}$ of incubation at room temperature, the optical density (OD) was measured with a micro-plate reader at $550 \mathrm{~nm}$.

\section{Results and Discussion}

\section{1. Chemistry}

The cobalt(III) complexes $\mathbf{1}$ and $\mathbf{2}$ were prepared by the reaction of $\mathrm{CoCl}_{2} \cdot 6 \mathrm{H}_{2} \mathrm{O}$ with the reduced Schiff base $\mathrm{H}_{2} \mathrm{~L}^{1}$, and $\mathrm{Co}\left(\mathrm{CH}_{3} \mathrm{COO}\right)_{2} \cdot 4 \mathrm{H}_{2} \mathrm{O}$ with the reduced Schiff base $\mathrm{H}_{3} \mathrm{~L}^{2}$, respectively in $\mathrm{MeOH}$ (Scheme 2). The aerial oxidation of cobalt(II) to cobalt(III) and metal assisted deprotonation of the phenolic moieties took place during the formation of the complexes. Molar conductivity values of complexes 1 and $\mathbf{2}$ measured in $\mathrm{MeOH}$ indicate the 1:1 electrolytic nature of complex $\mathbf{1}$ and non-electrolytic nature of complex $2 .{ }^{9}$

\section{2. Spectral Characterization}

In the IR spectra of the complexes, the bands corresponding to the azomethine groups $(-\mathrm{CH}=\mathrm{N}-)$ are not observed, instead, new bands indicative of the $\mathrm{C}-\mathrm{N}$ groups are observed at $1073-1085 \mathrm{~cm}^{-1}$, indicating the reduction of the $-\mathrm{CH}=\mathrm{N}$ - double bonds to the $-\mathrm{CH}_{2}-\mathrm{NH}-$ single bonds. The complexes show medium bands at 1213-1218 $\mathrm{cm}^{-1}$ due to the presence of Ar-O stretching. Weak and sharp bands for the spectra of the complexes located at $3245 \mathrm{~cm}^{-1}$ indicates the presence of amino groups. The weak and broad band centered at $3419 \mathrm{~cm}^{-1}$ for complex 2 can be assigned to the stretching vibration of water molecules.

The UV-Vis spectra of the complexes were measured in $\mathrm{MeOH}$. There are two bands centered at 280 and $372 \mathrm{~nm}$ for $\mathbf{1}$ and four bands centered at 210,263, 317 and $372 \mathrm{~nm}$ for 2 . The bands arise due to internal ligand transition or ligand to metal charge transfer. The complexes exhibit low intensity bands at 615-630 nm which are due to the $d-d$ transition of $\mathrm{Co}^{\mathrm{III}}$ center.

\section{3. Structure Description of the Complexes}

Selected bond lengths and bond angles in the coordination environment of the metal center are listed in Table 2. Complex 1 contains a mononuclear $\left[\mathrm{Co}\left(\mathrm{HL}^{1}\right)_{2}\right]^{+}$ cation and a chloride anion (Fig. 1). The cationic moiety possesses a crystallographic inversion symmetry. The Co atom, lying on the inversion center, is coordinated by two phenolate $\mathrm{O}$ and four amino $\mathrm{N}$ atoms from two $\mathrm{HL}^{1}$ ligands, forming octahedral coordination. The $\mathrm{Co}-\mathrm{O}$ and $\mathrm{Co}-\mathrm{N}$ bond lengths in the complex are in the range 1.906(3)-1.991(3) $\AA$, which are very close to those reported in literature. ${ }^{10}$ The cisoid $\left(85.8(1)-94.1(1)^{\circ}\right)$ and transoid angles $\left(180^{\circ}\right)$ in the complex are almost near to the ideal values.

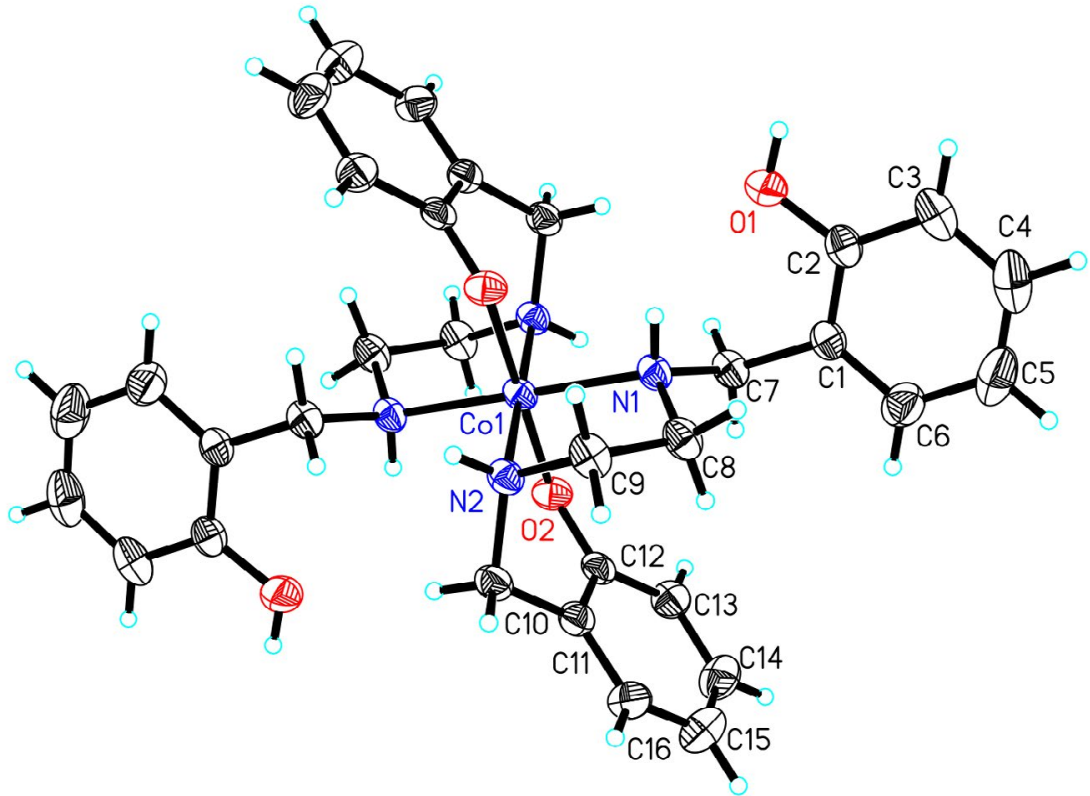

Fig. 1. The mononuclear complex cationic moiety of $\mathbf{1}$. The chloride anion is omitted for clarity. Displacement ellipsoids are drawn at the $30 \%$ probability level and $\mathrm{H}$ atoms are shown as small spheres of arbitrary radii. 


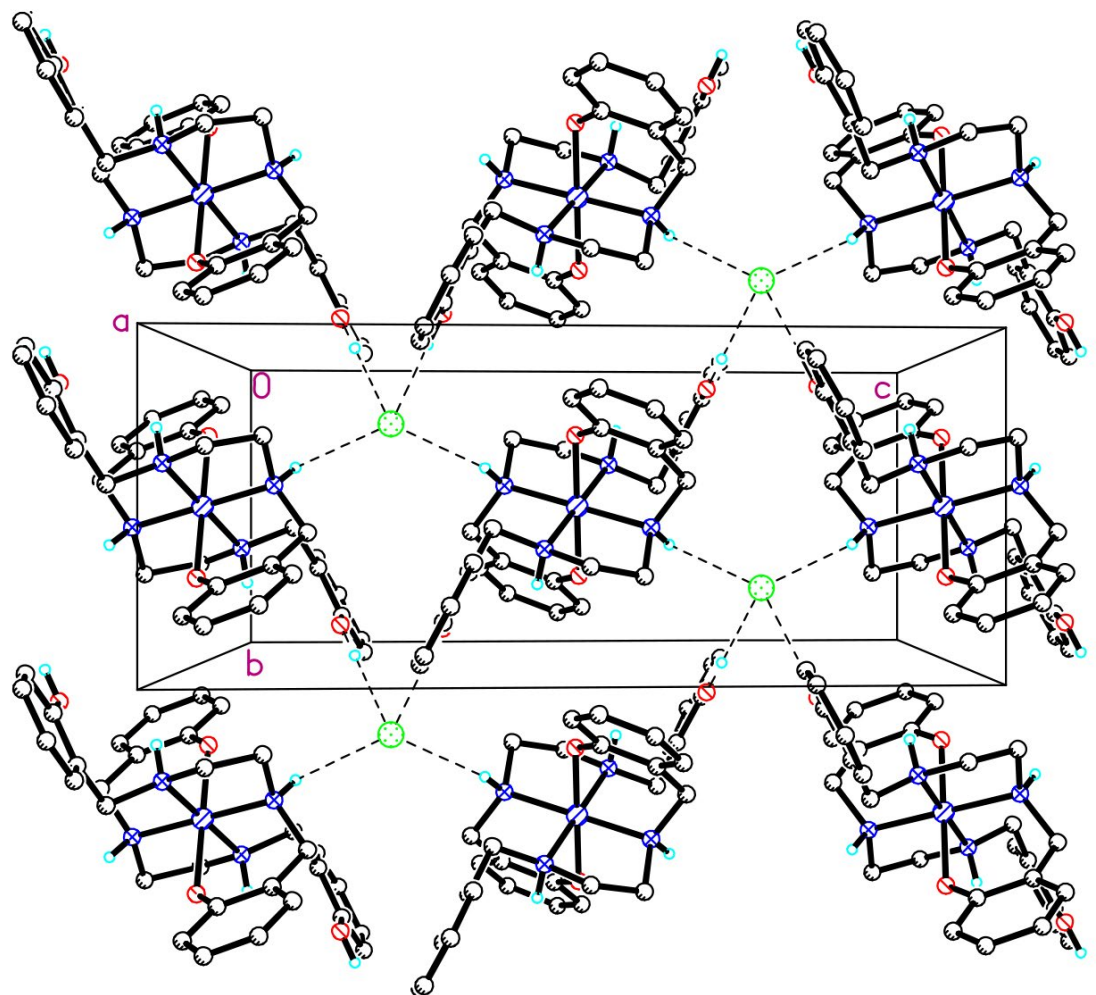

Fig. 2. Molecular packing structure of $\mathbf{1}$. Hydrogen bonds are shown as dashed lines.

In the crystal structure, the complex cations are linked by chloride anions through intermolecular hydrogen bonds of types $\mathrm{N}-\mathrm{H} \cdot \cdots \mathrm{Cl}, \mathrm{N}-\mathrm{H} \cdots \mathrm{O}$ and $\mathrm{O}-\mathrm{H} \cdots \mathrm{Cl}$ (Table 3), to form two-dimensional network along the $b c$ plane (Fig. 2).
Complex 2 contains a dinuclear $\left[\mathrm{Co}_{2}\left(\mathrm{~L}^{2}\right)_{2}\right]$ molecule and two water hydrate molecules (Fig. 3). The Col atom is coordinated by two phenolate $\mathrm{O}$, two amino $\mathrm{N}$, and two hydroxy $\mathrm{O}$ atoms from two $\mathrm{L}^{2}$ ligands, forming octahedral coordination. The $\mathrm{Co} 2$ atom is coordinated by two pheno-

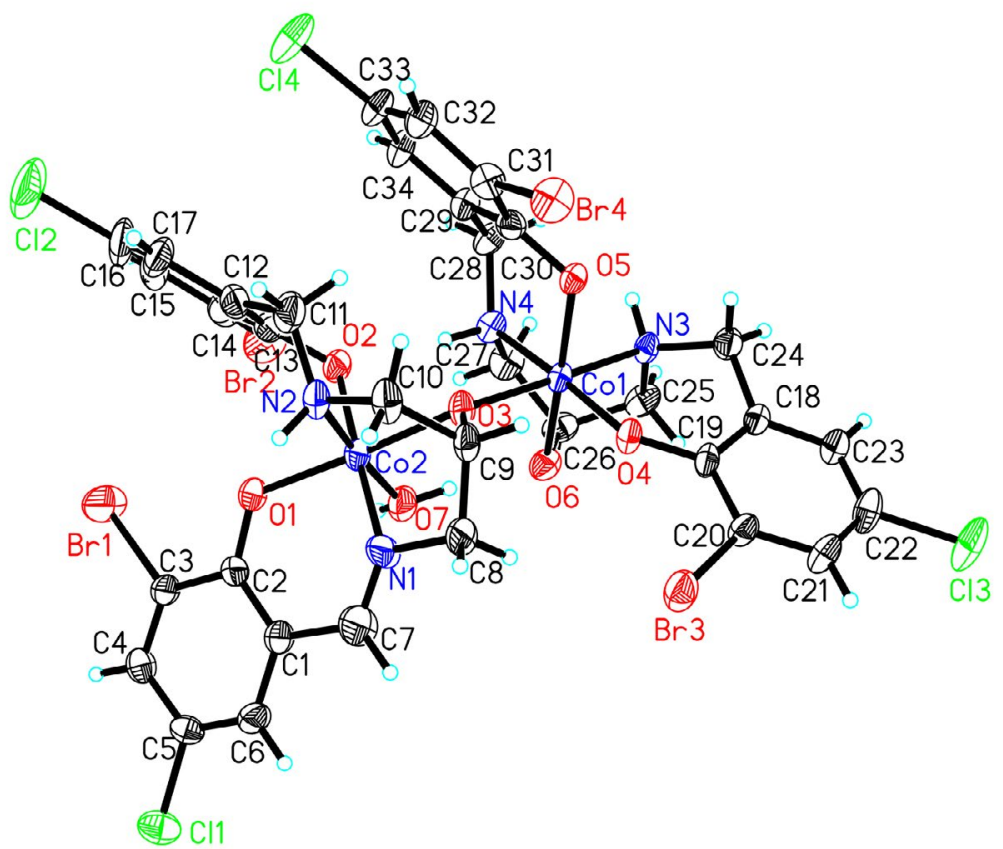

Fig. 3. The dinuclear complex moiety of $\mathbf{2}$. The two water molecules are omitted for clarity. Displacement ellipsoids are drawn at the $30 \%$ probability level and $\mathrm{H}$ atoms are shown as small spheres of arbitrary radii. 


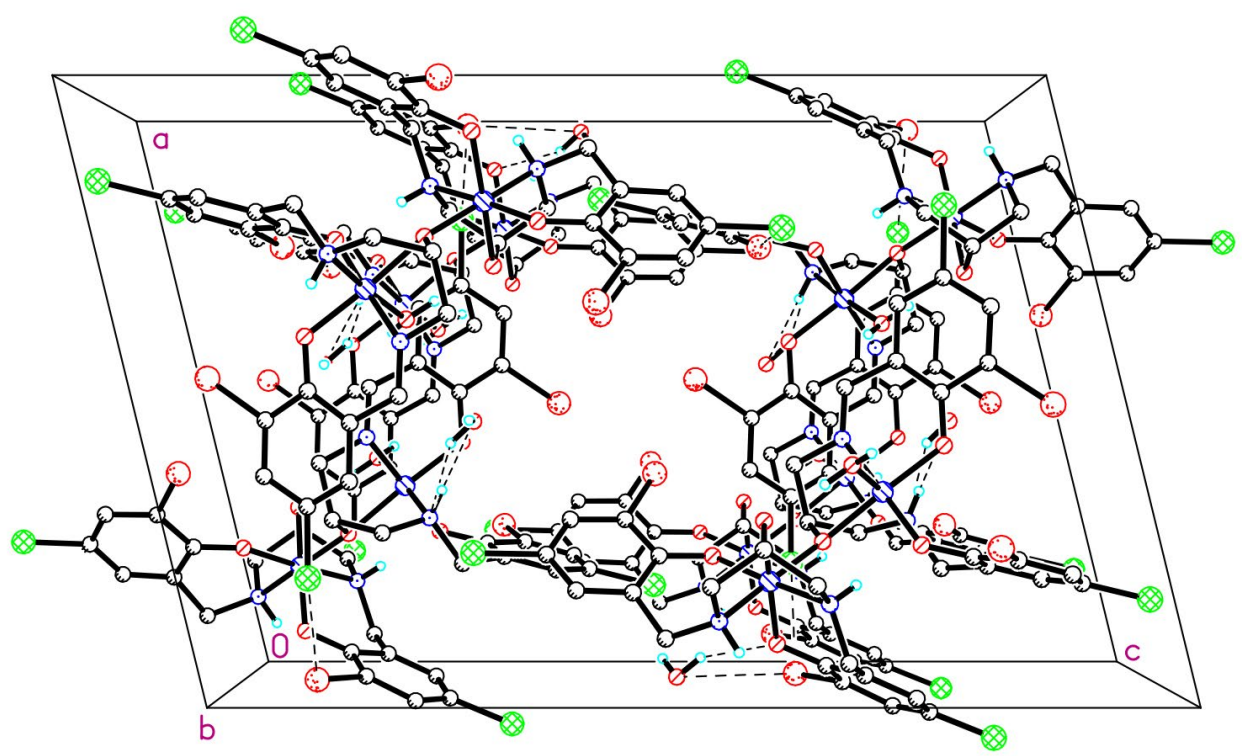

Fig. 4. Molecular packing structure of 2. Hydrogen bonds are shown as dashed lines.

late $\mathrm{O}$, two amino $\mathrm{N}$, and one hydroxy $\mathrm{O}$ atoms from one $\mathrm{L}^{2}$ ligand, and by one water $\mathrm{O}$ atom, forming octahedral coordination. The $\mathrm{Co}-\mathrm{O}$ and $\mathrm{Co}-\mathrm{N}$ bond lengths in the

Table 2. Selected bond lengths $(\AA)$ and angles $\left(^{\circ}\right)$ for the complexes

\begin{tabular}{|c|c|c|c|}
\hline \multicolumn{4}{|l|}{1} \\
\hline $\mathrm{Co} 1-\mathrm{O} 2$ & $1.906(3)$ & Co1-N2 & $1.951(3)$ \\
\hline Co1-N1 & $1.991(3)$ & & \\
\hline $\mathrm{O} 2-\mathrm{Co} 1-\mathrm{O} 2^{\# 1}$ & 180 & $\mathrm{O} 2-\mathrm{Co} 1-\mathrm{N} 2^{\# 1}$ & $85.9(1)$ \\
\hline $\mathrm{O} 2-\mathrm{Co} 1-\mathrm{N} 2$ & $94.1(1)$ & $\mathrm{N} 2-\mathrm{Co} 1-\mathrm{N} 2{ }^{\# 1}$ & 180 \\
\hline $\mathrm{O} 2-\mathrm{Co} 1-\mathrm{N} 1$ & $93.8(1)$ & $\mathrm{O} 2-\mathrm{Co} 1-\mathrm{N} 1^{\# 1}$ & $86.2(1)$ \\
\hline $\mathrm{N} 2-\mathrm{Co} 1-\mathrm{N} 1^{\# 1}$ & $93.7(1)$ & N2-Co1-N1 & $86.3(1)$ \\
\hline $\mathrm{N} 1-\mathrm{Co} 1-\mathrm{N} 1^{\# 1}$ & 180 & & \\
\hline \multicolumn{4}{|l|}{2} \\
\hline Co1-O4 & $1.893(6)$ & Co1-O6 & $1.905(7)$ \\
\hline Co1-N4 & $1.922(7)$ & Co1-O5 & $1.931(6)$ \\
\hline Co1-N3 & $1.942(7)$ & Co1-O3 & $1.957(6)$ \\
\hline $\mathrm{Co} 2-\mathrm{O} 1$ & $1.869(7)$ & $\mathrm{Co} 2-\mathrm{N} 1$ & $1.895(9)$ \\
\hline $\mathrm{Co} 2-\mathrm{O} 2$ & $1.892(7)$ & $\mathrm{Co} 2-\mathrm{O} 3$ & $1.929(6)$ \\
\hline $\mathrm{Co} 2-\mathrm{O} 7$ & $1.932(9)$ & $\mathrm{Co} 2-\mathrm{N} 2$ & $1.932(9)$ \\
\hline O4-Co1-O6 & 95.3(3) & $\mathrm{O} 4-\mathrm{Co} 1-\mathrm{N} 4$ & $176.9(3)$ \\
\hline O6-Co1-N4 & $81.9(3)$ & O4-Co1-O5 & $88.6(3)$ \\
\hline O6-Co1-O5 & $175.8(3)$ & N4-Co1-O5 & $94.2(3)$ \\
\hline O4-Co1-N3 & 94.3(3) & O6-Co1-N3 & $85.5(3)$ \\
\hline N4-Co1-N3 & $87.0(3)$ & O5-Co1-N3 & $92.7(3)$ \\
\hline O4-Co1-O3 & $90.1(3)$ & O6-Co1-O3 & $91.4(3)$ \\
\hline N4-Co1-O3 & $88.5(3)$ & O5-Co1-O3 & $90.1(3)$ \\
\hline N3-Co1-O3 & $174.8(3)$ & $\mathrm{O} 1-\mathrm{Co} 2-\mathrm{N} 1$ & $91.4(3)$ \\
\hline $\mathrm{O} 1-\mathrm{Co} 2-\mathrm{O} 2$ & $89.4(3)$ & $\mathrm{N} 1-\mathrm{Co} 2-\mathrm{O} 2$ & $175.8(4)$ \\
\hline $\mathrm{O} 1-\mathrm{Co} 2-\mathrm{O} 3$ & $173.3(4)$ & $\mathrm{N} 1-\mathrm{Co} 2-\mathrm{O} 3$ & 87.5(3) \\
\hline $\mathrm{O} 2-\mathrm{Co} 2-\mathrm{O} 3$ & $92.2(3)$ & $\mathrm{O} 1-\mathrm{Co} 2-\mathrm{O} 7$ & $92.9(3)$ \\
\hline $\mathrm{N} 1-\mathrm{Co} 2-\mathrm{O} 7$ & $90.3(4)$ & $\mathrm{O} 2-\mathrm{Co} 2-\mathrm{O} 7$ & $85.5(3)$ \\
\hline $\mathrm{O} 3-\mathrm{Co} 2-\mathrm{O} 7$ & $93.8(3)$ & $\mathrm{O} 1-\mathrm{Co} 2-\mathrm{N} 2$ & $91.2(4)$ \\
\hline $\mathrm{N} 1-\mathrm{Co} 2-\mathrm{N} 2$ & $89.1(4)$ & $\mathrm{O} 2-\mathrm{Co} 2-\mathrm{N} 2$ & $95.0(3)$ \\
\hline $\mathrm{O} 3-\mathrm{Co} 2-\mathrm{N} 2$ & $82.1(3)$ & $\mathrm{O} 7-\mathrm{Co} 2-\mathrm{N} 2$ & $175.9(3)$ \\
\hline
\end{tabular}

Symmetry code for \#1: $-x,-y, 1-z$. complex are in the range 1.871(6)-1.957(6) $\AA$, which are very close to those reported in literature. ${ }^{10}$ The cisoid (81.9(3)-95.3(3) $)^{\circ}$ for $\mathrm{Co} 1$ and 82.1(3)-95.0(3) ${ }^{\circ}$ for Co2) and transoid angles (174.8(3)-176.9(3) ${ }^{\circ}$ for $\mathrm{Co} 1$ and 173.3(4)-175.9(3) ${ }^{\circ}$ for Co2) in the complex are almost near to the ideal values.

In the crystal structure, the complex molecules and the water molecules are linked through intermolecular hydrogen bonds of types $\mathrm{O}-\mathrm{H} \cdots \mathrm{O}, \mathrm{O}-\mathrm{H} \cdots \mathrm{N}$ and $\mathrm{N}-\mathrm{H} \cdots \mathrm{O}$ (Table 3), to form two-dimensional network along the $a b$ plane (Fig. 4).

\section{4. Antibacterial Activity}

The free reduced Schiff base ligands and their cobalt(III) complexes were screened for antibacterial activity against two Gram-positive bacterial strains (B. subtilis and $S$. aureus) and two Gram-negative bacterial strains (E. coli and $P$. fluorescence) by the MTT method. The MIC values of the compounds against these bacteria are presented in Table 4. Penicillin G and kanamycin were assayed as references. $\mathrm{H}_{2} \mathrm{~L}^{1}$ is inactive against two Gram-positive bacterial strains $B$. subtilis and $S$. aureus, and has weak activity against the Gram-negative bacterial strains $E$. coli and $P$. fluorescence with MIC values of $25 \mu \mathrm{g} \mathrm{mL} \mathrm{m}^{-1} \mathrm{H}_{3} \mathrm{~L}^{2}$ is inactive against the Gram-negative bacterial strain $P$. fluorescence, and has weak activity against the Gram-negative bacterial strain E. coli and the Gram-positive bacterial strain S. aureus, with MIC values of $25 \mu \mathrm{g} \mathrm{mL} \mathrm{L}^{-1} \cdot \mathrm{H}_{3} \mathrm{~L}^{2}$ is active against the Gram-positive bacterial strain B. subtilis, with MIC value of $12.5 \mu \mathrm{g} \mathrm{mL}{ }^{-1}$. The cobalt(III) complexes, in general, showed a wide range of bactericidal activities against all the Gram-positive and Gram-negative bacteria. Complex 1 has good activity against the Gram-positive bacterial strain B. subtilis and medium activity against 
Table 3. Hydrogen bond distances $(\AA)$ and bond angles $\left(^{\circ}\right)$ for the complexes

\begin{tabular}{|c|c|c|c|c|}
\hline$D-\mathrm{H} \cdots \mathrm{A}$ & $d(D-\mathrm{H})$ & $d(\mathrm{H} \cdots A)$ & $d(D \cdots A)$ & $\angle(D-\mathrm{H} \cdots A)$ \\
\hline \multicolumn{5}{|l|}{1} \\
\hline $\mathrm{N} 2-\mathrm{H} 2 \cdots \mathrm{Cl}^{\# 1}$ & 0.89 & 2.50 & $3.246(3)$ & 142 \\
\hline N1-H1‥O1 & 0.90 & 2.45 & $3.011(4)$ & 120 \\
\hline $\mathrm{O} 1-\mathrm{H} 1 \mathrm{~A} \cdots \mathrm{Cl} 1$ & 0.84 & 2.24 & $3.068(3)$ & 171 \\
\hline \multicolumn{5}{|l|}{2} \\
\hline O7-H7A …66 & $0.85(1)$ & $1.68(3)$ & $2.507(10)$ & $162(9)$ \\
\hline O9-H9A …N2 & $0.85(1)$ & $2.28(6)$ & $3.048(17)$ & 151(11) \\
\hline 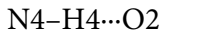 & $0.90(1)$ & $1.88(4)$ & $2.741(10)$ & 159(11) \\
\hline 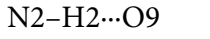 & $0.90(1)$ & $2.15(2)$ & $3.048(17)$ & 177(11) \\
\hline $\mathrm{O} 8-\mathrm{H} 8 \mathrm{~B} \cdots \mathrm{O} 5^{\# 2}$ & $0.85(1)$ & $2.18(5)$ & $2.966(11)$ & $154(10)$ \\
\hline $\mathrm{N} 3-\mathrm{H} 3 \cdots \mathrm{O} 8^{\# 3}$ & $0.90(1)$ & $2.23(7)$ & $2.999(12)$ & $143(10)$ \\
\hline
\end{tabular}

Symmetry codes: \#1: $-x,-y, 1-z$; \#2: $x, y, 1+z ; \# 3:-x, 3 / 2+y, 3 / 2-z$.

S. aureus, with MIC values of 3.12 and $12.5 \mu \mathrm{g} \mathrm{mL}^{-1}$, respectively. Complex 2 has good activity against both Gram-positive bacterial strains B. subtilis and S. aureus, with MIC values of 0.78 and $6.25 \mu \mathrm{g} \mathrm{mL}^{-1}$, respectively. As for the two Gram-negative bacterial strains $E$. coli and $P$. fluorescence, both complexes have excellent activities with MIC values of 1.56 and $0.78 \mu \mathrm{g} \mathrm{mL}^{-1}$ for 1 , and 3.12 and $6.25 \mu \mathrm{g} \mathrm{mL}^{-1}$ for 2 , respectively, which are stronger than the reference drug kanamycin.

Table 4. MIC values $\left(\mu \mathrm{g} \mathrm{mL}^{-1}\right)$ of the compounds

\begin{tabular}{lcccc}
\hline & B. subtilis & S. aureus & E. coli & P. fluorescence \\
\hline $\mathbf{1}$ & 3.12 & 12.5 & 1.56 & 0.78 \\
$\mathbf{2}$ & 0.78 & 6.25 & 3.12 & 6.25 \\
$\mathrm{H}_{2} \mathrm{~L}^{1}$ & $>100$ & $>100$ & 25 & 25 \\
$\mathrm{H}_{3} \mathrm{~L}^{2}$ & 12.5 & 25 & 25 & $>100$ \\
Penicillin G & 0.78 & 3.13 & $>100$ & $>100$ \\
Kanamycin & 0.39 & 1.56 & 6.25 & 6.25 \\
\hline
\end{tabular}

\section{Conclusion}

Two new cobalt(III) complexes with reduced Schiff base ligands 2,2'-((ethane-1,2-diylbis(azanediyl)) bis(methylene))diphenol and 6,6'-(2-hydroxypropane-1,3-diyl)bis(azanediyl)bis(methylene)bis(2-bromo-4-chlorophenol) have been synthesized and structurally characterized. One complex is in mononuclear and the other one is in dinuclear. The Co atoms are in octahedral coordination. The complexes showed potential antimicrobial activities against two Gram-positive bacterial strains (B. subtilis and S. aureus) and two Gram-negative bacterial strains (E. coli and P. fluorescence).

\section{References}

1. (a) J. L. Pratihar, P. Mandal, C. K. Lai, S. Chattopadhyay, Polyhedron 2019, 161, 317-324. DOI:10.1016/j.poly.2019.01.002 (b) V. S. Zanon, J. A. Lima, T. Cuya, F. R. S. Lima, A. C. C. da Fonseca, J. G. Gomez, R. R. Ribeiro, T. C. C. Franca, M. D. Vargas, J. Inorg. Biochem. 2019, 191, 183-193.

DOI:10.1016/j.jinorgbio.2018.11.019

(c) M. M. Duan, Y. M. Li, L. Y. Xu, H. L. Yang, F. W. Luo, Y. X. Guan, B. T. Zhang, C. L. Jing, Z. L. You, Inorg. Chem. Commun. 2019, 100, 27-31. DOI:10.1016/j.inoche.2018.12.009

(d) A. Banerjee, S. Chattopadhyay, Polyhedron 2019, 159, 1-11. DOI:10.1016/j.poly.2018.10.059

(e) S. Kumari, K. Maddipoti, B. Das, S. Ray, Inorg. Chem. 2019, 58, 1527-1540. DOI:10.1021/acs.inorgchem.8b03031

2. (a) F. Tok, B. Kocyigit-Kaymakcioglu, B. N. Saglik, S. Levent, Y. Ozkay, Z. A. Kaplancikli, Bioorg. Chem. 2019, 84, 41-50. DOI:10.1016/j.bioorg.2018.11.016

(b) G. Kapoor, D. P. Pathak, R. Bhutani, A. Husain, S. Jain, M. A. Iqbal, Bioorg. Chem. 2019, 84, 478-492.

DOI:10.1016/j.bioorg.2018.11.016

(c) P. T. Todorov, P. N. Peneva, S. I. Georgieva, R. I. Rusew, B. L. Shivachev, A. H. Georgiev, New J. Chem. 2019, 43, 27402751. DOI:10.1039/C8NJ05748F

3. (a) D. Majumdar, D. Das, S. S. Sreejith, S. Das, J. K. Biswas, M. Mondal, D. Ghosh, K. Bankura, D. Mishra, Inorg. Chim. Acta 2019, 489, 244-254. DOI:10.1016/j.ica.2019.02.022

(b) O. L. Cifuentes-Vaca, J. Andrades-Lagos, J. Campanini-Salinas, A. Laguna, D. Vasquez-Velasquez, M. C. Gimeno, Inorg. Chim. Acta 2019, 489, 275-279.

DOI:10.1016/j.ica.2019.02.033

(c) M. Karmakar, T. Basak, S. Chattopadhyay, New J. Chem. 2019, 43, 4432-4443. DOI:10.1039/C8NJ06549G

(d) H. Bahron, S. S. Khaidir, A. M. Tajuddin, K. Ramasamy, B. M. Yamin, Polyhedron 2019, 161, 84-92.

DOI:10.1016/j.poly.2018.12.055

(e) F. Forouzandeh, H. Keypour, M. H. Zebarjadian, M. Mahmoudabadi, L. Hosseinzadeh, R. Karamian, M. A. Khoei, R. W. Gable, Polyhedron 2019, 160, 238-246.

DOI:10.1016/j.poly.2018.12.052

(f) K. Jana, S. Das, H. Puschmann, S. C. Debnath, A. Shukla, A. K. Mahanta, M. Hossain, T. Maity, B. C. Samanta, Inorg. Chim. Acta 2019, 487, 128-137.

DOI:10.1016/j.ica.2018.12.007 
(g) X.-W. Zhu, Acta Chim. Slov. 2018, 65, 939-945. DOI:10.17344/acsi.2018.4607

(h) D.-L. Peng, N. Sun, Acta Chim. Slov. 2018, 65, 895-901. DOI:10.17344/acsi.2018.4543

4. V. Gomathi, R. Selvameena, Inorg. Chim. Acta 2018, 480, 42-46. DOI:10.1016/j.ica.2018.05.007

5. K. Ghosh, K. Harms, S. Chattopadhyay, ChemistrySelect 2017, 2, 8207-8220. DOI:10.1002/slct.201701536

6. (a) A. K. Ghosh, C. S. Purohit, R. Ghosh, Polyhedron 2018, 155, 194-201. DOI:10.1016/j.poly.2018.08.021

(b) P. Nithya, R. Rajamanikandan, J. Simpson, M. Ilanchelian, S. Govindarajan, Polyhedron 2018, 145, 200-217.

DOI:10.1016/j.poly.2018.02.008

(c) D. Bandyopadhyay, M. Layek, M. Fleck, R. Saha, C. Rizzoli, Inorg. Chim. Acta 2017, 461, 174-182.

DOI:10.1016/j.ica.2017.02.018
7. G. M. Sheldrick, SAINT (Version 6.02), SADABS (Version 2.03), Bruker AXS Inc., Madison, Wisconsin, 2002.

8. (a) G. M. Sheldrick, SHELXTL (Version 6.10), Bruker AXS Inc., Madison, Wisconsin, 2002.

(b) G. M. Sheldrick, SHELXL-97: A Program for Crystal Structure Solution, University of Göttingen, Göttingen, Germany, 1997.

9. W. J. Geary, Coord. Chem. Rev. 1971, 7, 81-122. DOI:10.1016/S0010-8545(00)80009-0

10. (a) E. T. Souza, L. C. Castro, F. A. V. Castro, L. D. Visentin, C. B. Pinheiro, M. D. Pereira, S. D. Machado, M. Scarpellini, J. Inorg. Biochem. 2009, 103, 1355-1365.

DOI:10.1016/j.jinorgbio.2009.07.008

(b) R. Shakya, C. Imbert, H. P. Hratchian, M. Lanznaster, M. J. Heeg, B. R. McGarvey, M. Allard, H. B. Schlegel, C. N. Verani, Dalton Trans. 2006, 21, 2517-2525.

DOI:10.1039/B514190G

\section{Povzetek}

Sintetizirali smo nov enojedrni kobaltov(III) kompleks, $\left[\mathrm{Co}\left(\mathrm{HL}^{1}\right)_{2}\right] \mathrm{Cl}(\mathbf{1}), \mathrm{z}$ uporabo reducirane Schiffove baze 2,2'-((etan-1,2-diilbis(azandiil))bis(metilen))difenol $\left(\mathrm{H}_{2} \mathrm{~L}^{1}\right)$, in nov dvojedrni kobaltov(III) kompleks, [Co $\left.{ }_{2}\left(\mathrm{~L}^{2}\right)_{2}\right]$. $2 \mathrm{H}_{2} \mathrm{O}(2)$, z uporabo reducirane Schiffove baze 6,6'-(2-hidroksipropan-1,3-diil)bis(azandiil)bis(metilen)bis(2-bromo4-chlorofenol) $\left(\mathrm{H}_{2} \mathrm{~L}^{2}\right)$. Kompleksa smo okarakterizirali z infrardečo in elektronsko spektroskopijo ter rentgensko monokristalno analizo. Predhodno smo sintetizirali ligande ter jih nato vezali na Co(III) centre. Spojina 1 vsebuje enojedrni $\left[\mathrm{Co}\left(\mathrm{HL}^{1}\right)_{2}\right]^{+}$kation in kloridni anion. Kation leži na kristalografskem centru inverzije. Spojina 2 vsebuje dvojedrne $\left[\mathrm{Co}_{2}\left(\mathrm{~L}^{2}\right)_{2}\right]$ molekule in dve molekuli hidratne vode. V kompleksih je Co atom oktaedrično koordiniran. Oba kompleksa izkazujeta potencialne protimikrobne lastnosti.

Except when otherwise noted, articles in this journal are published under the terms and conditions of the Creative Commons Attribution 4.0 International License 